\title{
Correction to: Description of trauma among French service members in the Department of Defense Trauma Registry: understanding the nature of trauma and the care provided
}

Marc A. Schweizer ${ }^{1 *}$, Jud C. Janak ${ }^{1}$, Zsolt T. Stockinger ${ }^{2}$ and Tristan Monchal ${ }^{3}$

\section{Correction to: Mil Med Res}

https://doi.org/10.1186/s40779-019-0197-6

After publication of this article [1], it was brought to our attention that the Fig. 2 is incorrect. The correct Fig. 2 is as below:

\footnotetext{
Author details

'United States Department of Defense Joint Trauma System, Joint Base San Antonio Fort Sam Houston, Houston, TX 78234, USA. ${ }^{2}$ Naval Medical

Readiness Training Command Jacksonville, Jacksonville, FL 32212, USA.

${ }^{3}$ Sainte Anne Military Hospital, BP 600, 83800 Toulon, Cedex 9, France.
}

Received: 1 July 2019 Accepted: 1 July 2019

Published online: 28 July 2019

\section{Reference}

1. Schweizer MA, et al. Description of trauma among French service members in the Department of Defense Trauma Registry: understanding the nature of trauma and the care provided. Mil Med Res. 2019;6:7 https://doi.org/10.11 86/s40779-019-0197-6.

\footnotetext{
* Correspondence: marc.a.schweizer2.ctr@mail.mil

${ }^{1}$ United States Department of Defense Joint Trauma System, Joint Base San

Antonio Fort Sam Houston, Houston, TX 78234, USA

Full list of author information is available at the end of the article
}

(c) The Author(s). 2019 Open Access This article is distributed under the terms of the Creative Commons Attribution 4.0 International License (http://creativecommons.org/licenses/by/4.0/), which permits unrestricted use, distribution, and reproduction in any medium, provided you give appropriate credit to the original author(s) and the source, provide a link to the Creative Commons license, and indicate if changes were made. The Creative Commons Public Domain Dedication waiver (http://creativecommons.org/publicdomain/zero/1.0/) applies to the data made available in this article, unless otherwise stated. 


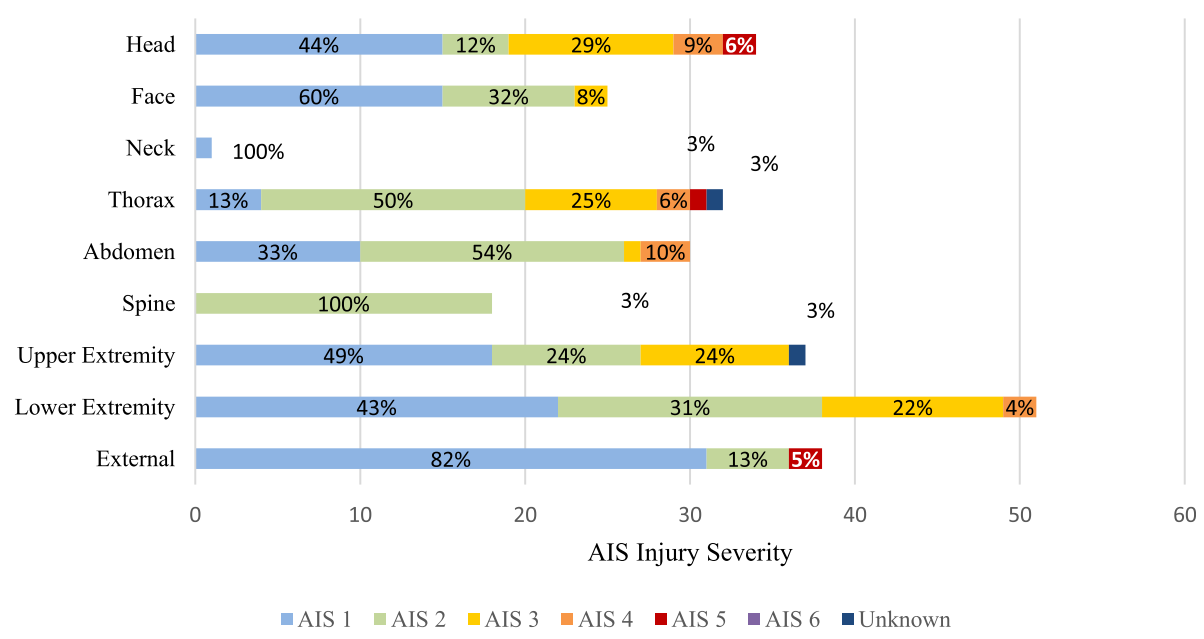

Fig. 2 Proportions of injuries among French Service Members treated in U.S. Medical Treatment Facilities per Body Region and AIS severity. AIS Abbreviated Injury Scale 